\title{
Predicting small mammal and flea abundance using landform and soil properties in a plague endemic area in Lushoto District, Tanzania
}

\author{
JOEL L. MELIYO', DIDAS N. KIMARO ${ }^{2}$, BALTHAZAR M. MSANYA ${ }^{1 *}$, LOTH S. MULUNGU ${ }^{3}$, PROCHES \\ HIERONIMO ${ }^{2}$, NGANGA I. KIHUPI ${ }^{2}$, HUBERT GULINCK ${ }^{4}$ and JOZEF A. DECKERS ${ }^{4}$ \\ ${ }^{1}$ Department of Soil Science, Sokoine University of Agriculture, P.O. Box 3008, Morogoro, Tanzania \\ ${ }^{2}$ Department of Agricultural Engineering and Land Planning, Sokoine University of Agriculture, P.O. Box 3003, \\ Morogoro, Tanzania \\ ${ }^{3}$ Pest Management Centre, Sokoine University of Agriculture, P. O. Box 3110, Morogoro, Tanzania \\ ${ }^{4}$ Department of Earth \& Environmental Sciences, Katholieke Universiteit Leuven, Celestijnenlaan 200 E, B-3001 \\ Heverlee, Belgium
}

\begin{abstract}
Small mammals particularly rodents, are considered the primary natural hosts of plague. Literature suggests that plague persistence in natural foci has a root cause in soils. The objective of this study was to investigate the relationship between on the one hand landforms and associated soil properties, and on the other hand small mammals and fleas in West Usambara Mountains in Tanzania, a plague endemic area. Standard field survey methods coupled with Geographical Information System (GIS) technique were used to examine landform and soils characteristics. Soil samples were analysed in the laboratory for physico-chemical properties. Small mammals were trapped on pre-established landform positions and identified to genus/species level. Fleas were removed from the trapped small mammals and counted. Exploration of landform and soil data was done using ArcGIS Toolbox functions and descriptive statistical analysis. The relationships between landforms, soils, small mammals and fleas were established by generalised linear regression model (GLM) operated in $R$ statistics software. Results show that landforms and soils influence the abundance of small mammals and fleas and their spatial distribution. The abundance of small mammals and fleas increased with increase in elevation. Small mammal species richness also increases with elevation. A landform-soil model shows that available phosphorus, slope aspect and elevation were statistically significant predictors explaining richness and abundance of small mammals. Fleas' abundance and spatial distribution were influenced by hill-shade, available phosphorus and base saturation. The study suggests that landforms and soils have a strong influence on the richness and evenness of small mammals and their fleas' abundance hence could be used to explain plague dynamics in the area.
\end{abstract}

Keywords: landform, soil properties, small mammals, flea, abundance, plague, Tanzania

\section{Introduction}

Small mammals (particularly rodents) are considered to be the primary natural hosts and reservoirs of Yersinia pestis. Worldwide, this disease infects about 203 rodent species (Gage \& Kasey, 2005; Sternest et al., 2008). Several studies in the West Usambara Mountains in Lushoto Tanzania have shown a large diversity of small mammals and fleas implicated as plague hosts and vectors, respectively (Kilonzo \& Msangi, 1991; Laudisoit et al., 2007). Furthermore, Kamugisha et al. (2007) and Neerinckx et al. (2010) have found that plague reported cases were located at elevations above 1,500m in Lushoto, Tanzania. Similar results have been reported in Uganda that plague cases are common in areas above 1300m (MacMillan et al., 2011; Eisen et al., 2012). The above studies agree with Pavlovsky (1966), Rotshild (1978) and Meade \& Earickson (2000) who associated the occurrence of plague disease with landform factors, which are envisaged to influence presence, reproduction of hosts and vectors and their interactions with humans.

In addition, soil may be an important reservoir, with burrowing animals acting as the first link in the transmission chain to other animals and humans through flea bites (Drancourt, 2006). Some literature indicates that plague persistence in natural foci has a root cause in soils (Breneva

\footnotetext{
*Correspondence: Balthazar M. Msanya; E-mail: bmmsanya@gmail.com
} 
et al., 2006; Eisen et al., 2008). This indication has been supported by the evidence that $Y$. pestis can survive in natural soil conditions from 24 days (Eisen et al., 2008) to 40 weeks (Ayyadurai et al., 2008). Additionally, there is a long standing hypothesis linking enzootic and epizootic plague cycles with soil micro-organisms like amoeba and soil organic matter (Anisimov, 2002) which come in contact with burrowing rodents. Through interaction of sylvatic and commensal rodents disease pathogens are exchanged through vectors such as fleas (Witmer, 2004).

It is envisaged that understanding landforms and the associated soil properties in the West Usambara Mountains may provide an insight into plague foci, with respect to rodents as plague hosts, and hence explain the differences in plague occurrence between neighbouring villages. This study was aimed at examining landforms and associated soil properties in relation to the presence of small mammals (rodents) and fleas, in order to contribute information to explain the presence and persistence of plague focus in West Usambara Mountains in north-eastern Tanzania.

\section{Materials and methods}

\section{Study area}

The study was carried out between September 2009 and June 2013 in the West Usambara Mountains, Lushoto District, Tanzania, in a rectangular section between $4^{\circ} 55^{\prime} \mathrm{S}, 38^{\circ} 14^{\prime} \mathrm{E}$ (northwest corner) and $4^{\circ} 71^{\prime} \mathrm{S}, 38^{\circ} 33^{\prime} \mathrm{E}$ (southeast corner). The elevation of the study area ranges from 300 to $2,270 m$ above sea level. Lushoto is among the most densely populated districts in Tanzania, with population density of 254 persons per $\mathrm{km}^{2}$, as compared with the national average of 39 persons per $\mathrm{km}^{2}$ (URT, 2013).

The topography in the study area is characterised from west to east by an undulating to rolling plain, sided by a rocky escarpment with an abrupt vertical rise. The escarpment is adjoined with a strongly dissected plateau composed of narrow crests and steep sided ridges separated by narrow valley bottoms, some with permanent streams. The annual precipitation varies from $600 \mathrm{~mm}$ in the Plain to $900 \mathrm{~mm}$ in the Escarpment and the Plateau. The average annual temperature ranges from $27^{\circ} \mathrm{C}$ to $17^{\circ} \mathrm{C}$ in a toposequence from the Plain to the Plateau.

Dominant soils are a continuum of shallow to very deep, red to dark reddish brown topsoils overlying well drained, red to yellowish red subsoils. Imperfectly drained soils dominate the valley bottoms. Soils of the Escarpment are shallow and rocky with pockets of deep, well drained to exhaustively drained soils. Natural forest reserve (Magamba) and plantation forests (Shume-Nywelo) dominate the south-western part of the study area, whereas agricultural activities intermittent with woodlots and agro forestry are dominant in the other parts of the Plateau.

\section{Determination of landform attributes}

A digital elevation model was obtained from Advanced Spaceborne Thermal Emission and Reflection Radiometer, Global Digital Elevation Model (ASTER-DEM) with $30 \mathrm{~m}$ ground resolution. It was used to derive landform attributes i.e. elevation, slope gradient, slope aspect, slope curvature (plan, profile, tangential, cross-section and general curvatures), and hill-shade. Continuous surface flow direction and flow accumulation were computed using Algorithms available in ArcGIS 9.3 Tool Box. Intensive field verification was done. Sites at which soil sampling and trapping of small mammals were carried out were superimposed and point data from individual landform characteristics were extracted using ArcGIS 9.3. The point data were used as landform variables in regression analysis.

\section{Determination of soil properties}

In each representative landform, soil samples were taken from surface soils at a depth of 0-45 $\mathrm{cm}$, which is considered the maximum depth of most rodent burrows (Brabers, 2012). Soil 
samples were analysed in the laboratory for texture, $\mathrm{pH}_{\text {water }}$, total nitrogen ( $\left.\mathrm{TN}\right)$, organic carbon (OC), cation exchange capacity (CEC), exchangeable bases and micronutrients as per procedures described by Moberg (2000). A total of 57 soil samples were collected from corresponding 57 geo-referenced sites. The laboratory data were organised in spreadsheets for regression analysis.

\section{Determination of the abundance of small mammals and fleas}

Trapping of small mammals was conducted twice, between December 2009 and March 2010, on sites where soil samples were collected. Three types of traps were used to capture small mammal species in the field: (i) Sherman live traps $(23 \times 9.5 \times 8 \mathrm{~cm})$, (ii) locally made wire cages (for bigger sized small mammals like squirrel, genetta), and (iii) the pitfall traps (10-litre plastic buckets). The total number of traps was 300 of which 270 were Sherman, 15 wire cages and 15 pitfalls. The traps were provided with bait and arranged in lines of 10 and placed $10 \mathrm{~m}$ apart. They were left open during the day and night for two consecutive nights. The baits used were plant butter mixed with bran roasted maize grain and sardine. Traps were inspected every morning between 08.00 and $10.00 \mathrm{hr}$ whereby those with catches were replaced by spare traps and bait. The trapped small mammals were counted, measured and identified to genus/species level following the nomenclature by Kingdon $(1974,1997)$. The fleas were removed from small mammals by brushing the fur using ethanol, counted, recorded and stored for identification in the laboratory. The data for small mammals and fleas were organised per specific landform in a spread sheet for data analysis.

\section{Data analysis}

Species diversity was measured using the Shannon Index (Shannon, 1948) as follows: $\mathrm{H}^{\prime}=-\sum_{i-1}^{S} \frac{n i}{N} \ln \left(\frac{n i}{N}\right)$

Where: $\mathrm{H}^{\prime}$ = is the Shannon diversity index,

$\mathrm{S}=$ species richness (number of species), and

$n i=$ is the number of individuals in the $i^{\text {th }}$ species,

$\frac{n i}{N}=$ proportion abundance contributed by the $\mathrm{i}^{\text {th }}$ species to the total

$\mathrm{N}=$ is the total number of individuals small mammals.

Relative abundance of small mammals was estimated by the formula:

Relative abundance $(\mathrm{RA})=\quad$ Number of individuals captured $\times 100$

Number of trap-nights (TN)

where one trap night $=$ one trap set for one night.

Regression analysis was used to establish relationships between small mammals' and fleas' abundances (dependent variables) and landform attributes and associated soil properties (independent variables). This was done using generalised linear Model (GLM) in R software (Fellows, 2012). The occurrence of small mammals and fleas in different landforms was validated using model goodness of fit given by pseudo R-squared $\left(D^{2}\right)$ and Akaike information criteria (AIC), whereby a model with the smallest AIC and high pseudo R-squared was selected as good among different regression repeats.

\section{Ethical considerations}

This study received approval from Directorate of Research and Post-Graduate Studies of Sokoine University of Agriculture, Tanzania and Flemish Inter-University Council (VLIR-UOS) of Belgium. 


\section{Results}

\section{Landform characteristics}

Figure 1 presents major landforms and their associated characteristics, which are strongly influenced by geologic composition, folding and faulting (Figure 2). Field and geologic data show elevation differences and strong dissection as indicated by cross-section A-B, and a complex system of elongated terraced ridges separated by narrow to wide drainage U-shaped valleys (converging hydrological flows). The steep slopes between dissected ridges are characterised by localised rock outcrops, scarps and in places landslide scars with shallow soils (Figure 1 and 2).

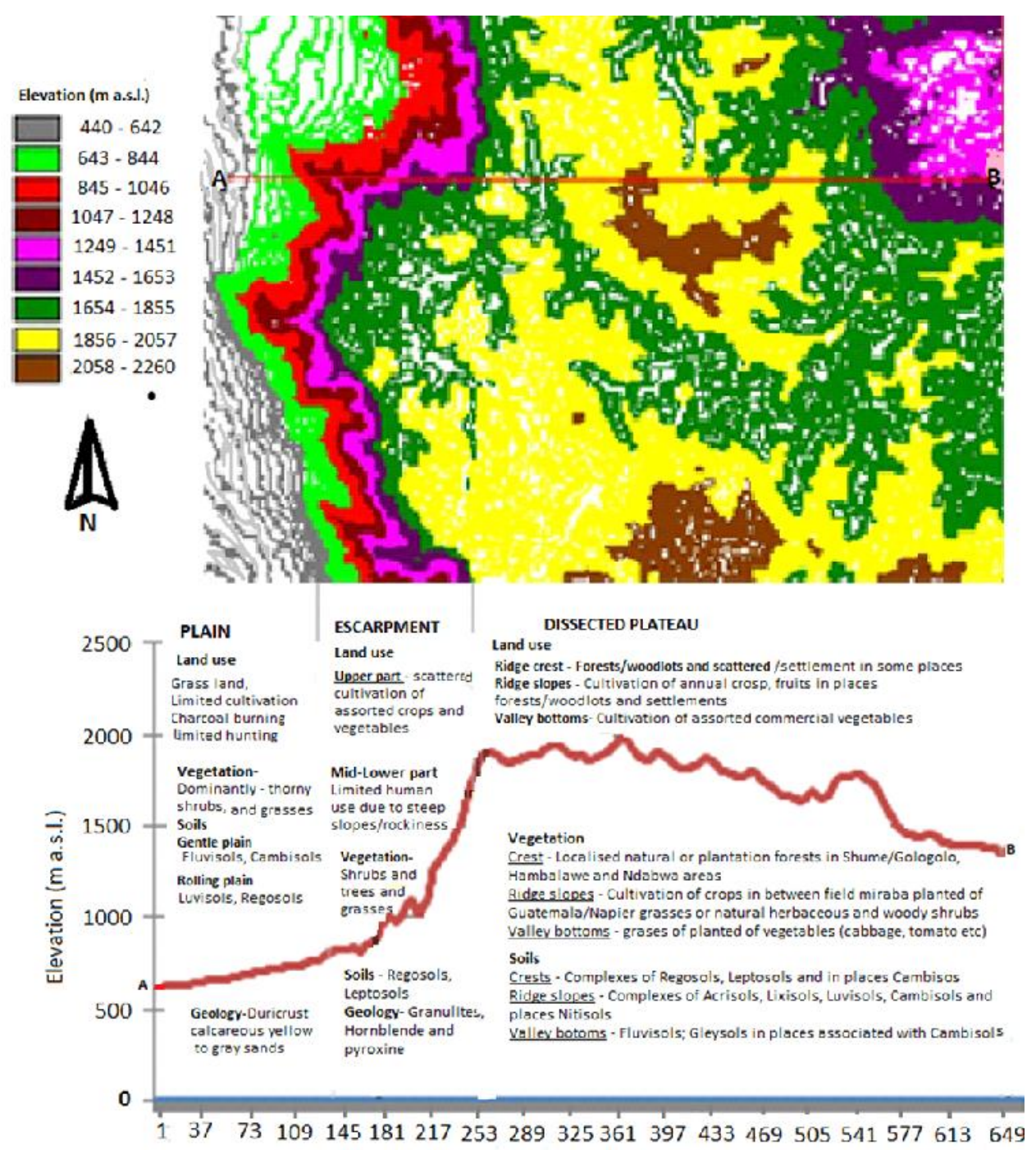

Figure 1: Major landform characteristics of the study area

The study area is dominantly covered by three major types of rocks corresponding to the studied three major landforms (Figures 1 and 2). The plain part of the study area is mainly covered by duricrust calcareous yellow to grey sands, while the escarpment is composed of undifferentiated granulites and distinctive bands of hornblende and pyroxene. The plateau dominantly has leucocratic quartzo-feldspathic granulites, khondalites and high level ferralitic red earths with inclusions of distinctive bands predominated by hornblende, pyroxene and granulite rocks and minerals and in depressions alluvium. The different geologic rocks weather differently when 
acted upon by land forming processes to form the observed landforms and soils. These in turn influence surface and subsurface water flows, vegetation, food and water availability which impact on small mammals' abundance.

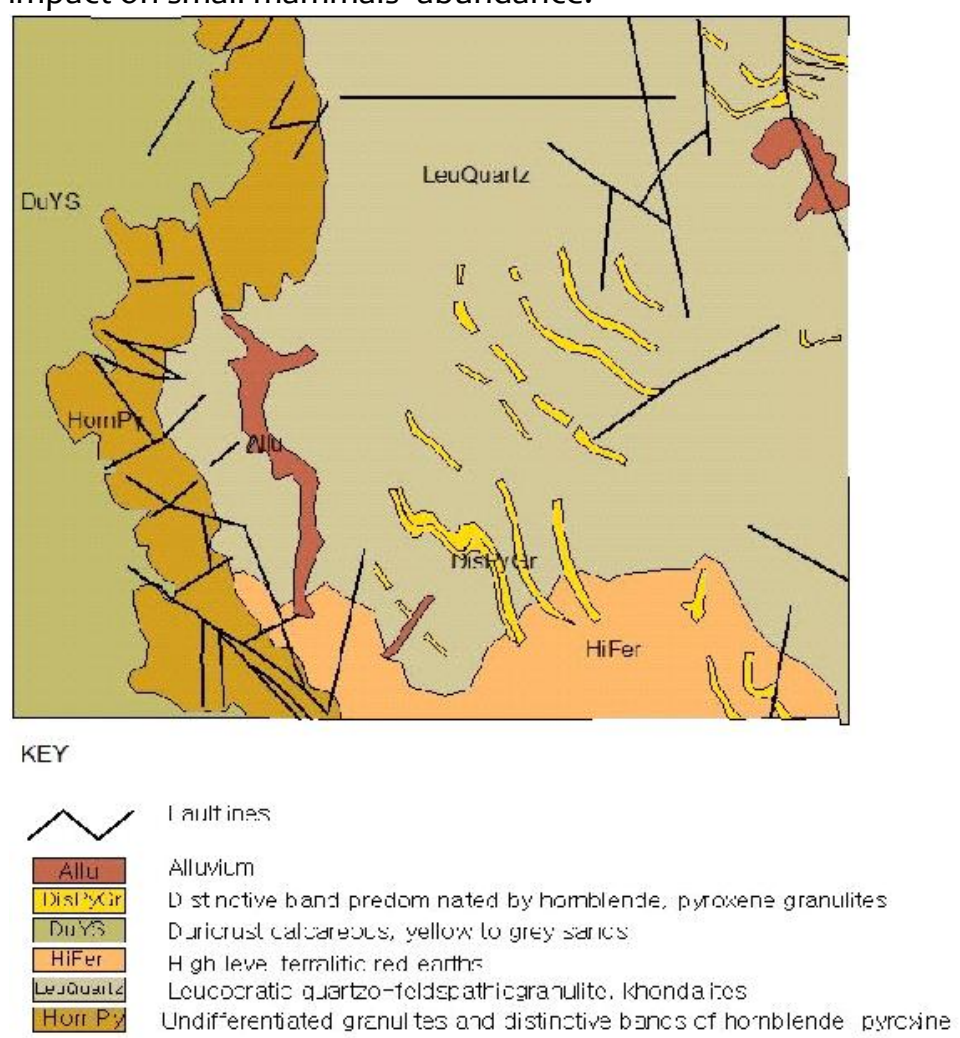

Figure 2: Spatial distribution of geologic composition showing dominant rocks and fault lines

Steep slopes along edges of fault lines are characterised by deep incision due to hydrological accelerated weathering of rocks as rain water flows along and within the cracks resulting into canyons, rock lees, and with time narrow valleys (Figure 3). It also shows pockets of soils and vegetation establishment due to fault lines' influence on surface water flows which in many instances serve as streams or river channels. The far end show trees along the fault line.

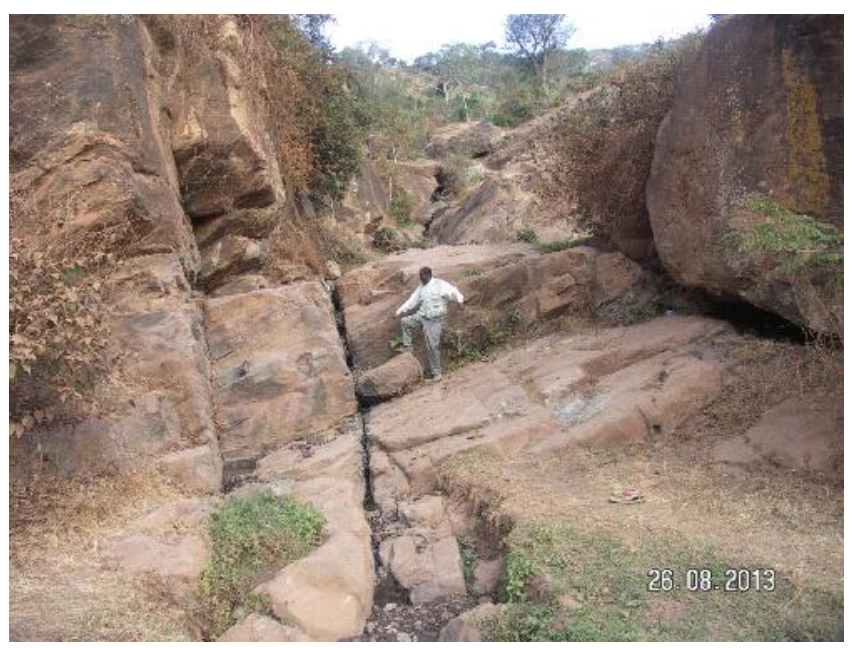

Figure 3: A fault line in the escarpment showing rock outcrop, with crevices and rock lees which serve as hiding places to small mammals 
Figure 4 presents the slope aspect, a multi-directional representation of surface slopes in degrees reading clockwise from $0^{\circ}$ (North), $90^{\circ}$ (East), $180^{\circ}$ (South) $270^{\circ}$ (West). Aspect influences the intensity and duration of solar energy the surface receives and hence rock weathering into soils and vegetation growth. So it differentiates the landscape in terms of food resources and habitats for small mammals.

\section{Soil properties associated with studied landforms}

Table 1 presents soil properties in the study area depicting correlation of soil parameters with the studied landforms. Results show that soils have more sand in the Plains which decreases with elevation and becomes clayey in the Plateau. The organic carbon content varies with landform units, with values ranging from 0.6 to $2.9 \%$ for the Plain and Plateau respectively. Results further show that micronutrients show an increase from low in the Plain to very high levels of iron ( $\mathrm{Fe})$ and manganese $(\mathrm{Mn})$ in the Plateau. Copper (Cu) and zinc ( $\mathrm{Zn}$ ) levels are within most plant critical levels (Deb \& Sakal, 2002) in the Plateau.

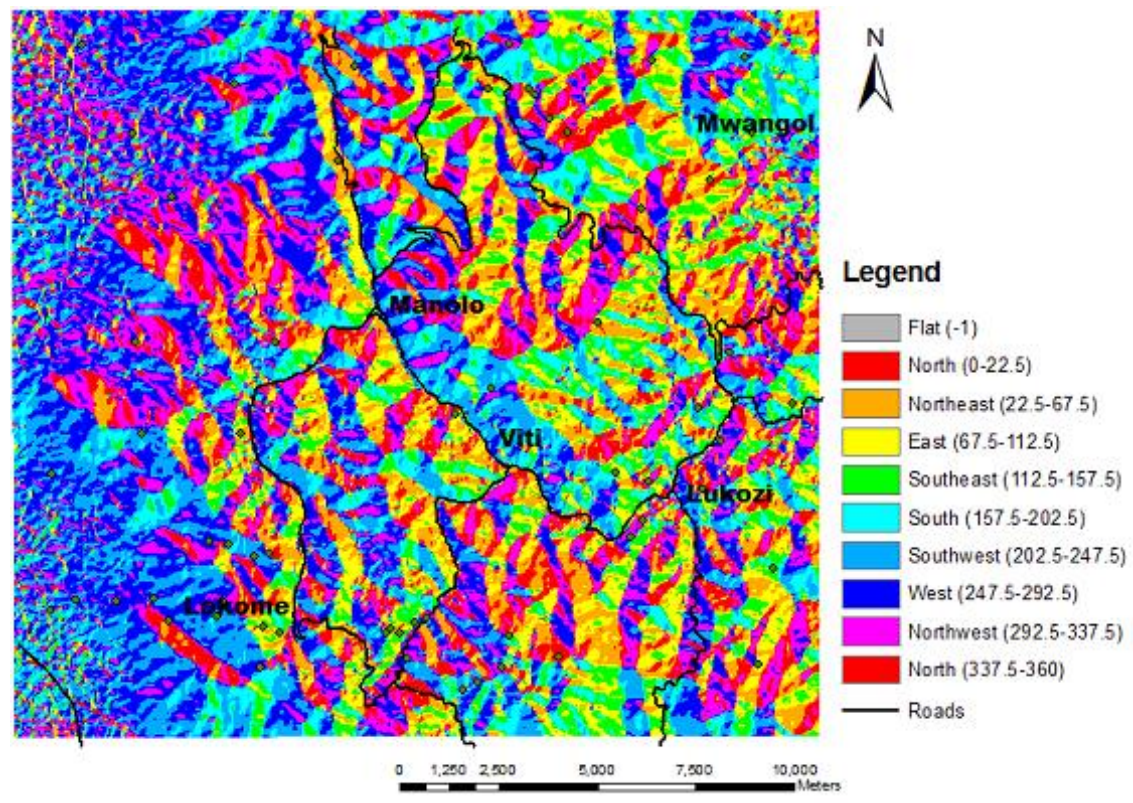

Figure 4: Slope aspect of the study area, showing different directions the slope is pointing

Table 1: Selected soil physical and chemical properties in the study area $(n=57)$

\begin{tabular}{|c|c|c|c|c|c|c|c|c|c|c|c|c|c|}
\hline \multirow[t]{2}{*}{ Landforms } & \multicolumn{3}{|c|}{ Particle size distribution } & \multirow{2}{*}{$\begin{array}{l}\mathrm{pH} \\
\left(\mathrm{H}_{2} \mathrm{O}\right)\end{array}$} & \multirow{2}{*}{$\begin{array}{l}O C \\
(\%)\end{array}$} & \multirow{2}{*}{$\begin{array}{l}\text { CEC } \\
\mathrm{cmol} \\
(+) / \mathrm{kg} \text { soil }\end{array}$} & \multicolumn{3}{|c|}{ Exchangeable bases } & \multicolumn{2}{|c|}{$\begin{array}{l}\text { DTPA } \\
\text { micronutrients }\end{array}$} & \multicolumn{2}{|c|}{ extractable } \\
\hline & $\begin{array}{l}\text { Clay } \\
(\%)\end{array}$ & $\begin{array}{l}\text { Sand } \\
(\%)\end{array}$ & $\begin{array}{l}\text { Silt } \\
(\%)\end{array}$ & & & & $\begin{array}{l}\mathrm{Ca} \\
\mathrm{cmol}\end{array}$ & $\begin{array}{l}\mathrm{Mg} \\
+/ \mathrm{kg}\end{array}$ & K & $\begin{array}{l}\mathrm{Fe} \\
\mathrm{mg} / \mathrm{kg}\end{array}$ & Mn & $\mathrm{Cu}$ & $\mathrm{Zn}$ \\
\hline Plain & 18.41 & 69.74 & 11.85 & 7.9 & 0.61 & 12.1 & 8.9 & 2.9 & 0.34 & 10.6 & 47.4 & 2.27 & 0.29 \\
\hline Escarpment & 26.59 & 61.15 & 12.26 & 7.6 & 2.77 & 18.1 & 13.9 & 1.9 & 0.29 & 29.53 & 139.6 & 2.16 & 1.73 \\
\hline Plateau & 52.48 & 38.7 & 8.82 & 5.7 & 2.91 & 18.3 & 7.1 & 2.2 & 0.15 & 107.3 & 63.1 & 2.07 & 1.62 \\
\hline
\end{tabular}

\section{Small mammals and fleas abundance along the studied landforms}

Results show that the abundance of small mammals and fleas, and small mammal species diversity increased with increasing elevation. The small mammal species relative abundance shows that Praomys spp., Mastomys spp. and Lophuromys spp. are dominant rodent species on 
the plateau, whereas Grammomys spp., Lophuromys spp., Aethomys spp. and Otomys spp., dominate the escarpment and Acomys spp., Praomys spp. and Paraxerus spp. are dominantly found in the plain. Results further show that Mastomys spp., are also found in the upper part of escarpment characterised by crop cultivation (Table 2).

Table 2: Small mammal abundance and species diversity and corresponding flea abundance

\begin{tabular}{|c|c|c|c|c|c|c|}
\hline Landforms & $\begin{array}{l}\text { Altitude } \\
\text { range }(\mathrm{m})\end{array}$ & $\begin{array}{l}\text { Slope } \\
\text { gradient } \\
(\%)\end{array}$ & Genus/Species & $\begin{array}{l}\text { Mammal } \\
\text { abundance }\end{array}$ & $\begin{array}{l}\text { Fleas } \\
\text { Abundance }\end{array}$ & $\begin{array}{l}\text { Mammal } \\
\text { diversity } \\
\text { index }\end{array}$ \\
\hline \multirow[t]{3}{*}{ Undulating plain } & $510-531$ & $4-7$ & Acomys & 46.7 & 14 & \\
\hline & & & Mungos & 12.5 & 0 & \\
\hline & & & Paraxerus & 16.7 & 0 & \\
\hline \multirow[t]{4}{*}{ Rolling Plain } & 696 & $12-15$ & Genetta & 9.1 & 5 & 1.58 \\
\hline & & & Paraxerus & 21.4 & 1 & \\
\hline & & & Acomys & 50.0 & 0 & \\
\hline & 704 & & Praomys & 33.3 & 0 & \\
\hline \multirow[t]{2}{*}{ Lower escarpment } & $765-807$ & $15-30$ & Aethomys & 16.7 & 15 & \\
\hline & 878 & 56 & Acomys & 12.5 & 0 & \\
\hline \multirow[t]{6}{*}{ Upper escarpment } & $1159-1604$ & $32-80$ & Aethomys & 43.8 & 5 & \\
\hline & $1123-1604$ & $45-55$ & Grammomys & 50.0 & 1 & 1.62 \\
\hline & & & Lophuromys & 50.0 & 4 & \\
\hline & & & Mastomys & 50.0 & 0 & \\
\hline & & & Otomys & 50.0 & 0 & \\
\hline & & & Praomys & 25.0 & 0 & \\
\hline \multirow[t]{2}{*}{ Plateau } & 1885 & 23 & Aethomys & 50.0 & 2 & \\
\hline & 1887 & & Crocidura & 60.0 & 0 & \\
\hline \multirow{7}{*}{$\begin{array}{l}\text { Sloping ridge } \\
\text { Plateau }\end{array}$} & $1771-1918$ & $20-90$ & Grammomys & 68.6 & 40 & \\
\hline & 1887 & $20-90$ & Lophuromys. & 71.8 & 19 & \\
\hline & 1739 & $20-90$ & Mastomys & 110.8 & 32 & 1.69 \\
\hline & 1739 & $7-70$ & Mouse legeda & 36.4 & 0 & \\
\hline & $1771-2011$ & $20-90$ & Praomys & 100.0 & 44 & \\
\hline & 1900-1904 & $20-90$ & Rattus rattus & 40.0 & 2 & \\
\hline & $1753-1903$ & $20-70$ & Crocidura & 33.3 & 0 & \\
\hline
\end{tabular}

Table 3: Soil and landform predictors for small mammals' distribution along the landscape

\begin{tabular}{|c|c|c|c|c|}
\hline S/ No. & AIC & Pseudo R-squared & Statistically signifi & ant predictors \\
\hline \multirow[t]{4}{*}{1} & 247.1 & 55.2 & Aspect & $* *$ \\
\hline & & & Ap-base saturation & * \\
\hline & & & Elevation & $* *$ \\
\hline & & & Available Bray P & $* * *$ \\
\hline \multirow[t]{4}{*}{2} & 250.3 & 61.2 & Aspect & * \\
\hline & & & Ap-base saturation & \\
\hline & & & Elevation & $* *$ \\
\hline & & & Available Bray P & $* * *$ \\
\hline \multirow[t]{3}{*}{3} & 255 & 49.4 & Elevation & $* *$ \\
\hline & & & Ap-sand & \\
\hline & & & Available Bray P & $* * *$ \\
\hline \multirow[t]{2}{*}{4} & 256.6 & 50.2 & Elevation & $* *$ \\
\hline & & & Available Bray P & $* * *$ \\
\hline \multirow[t]{2}{*}{5} & 257.5 & 42.4 & Elevation & * \\
\hline & & & Available Bray P & \\
\hline
\end{tabular}




\section{Influence of landforms and associated soil properties on small mammals abundance}

The results demonstrate a significant relationship between the occurrence of small mammals and fleas with elevation and aspect. Available phosphorus (P) showed a significant correlation with the occurrence of small mammals and fleas. The best two models explained between 55 to $61 \%$ (Table 3) of the variance observed in the prediction of small mammals' abundance.
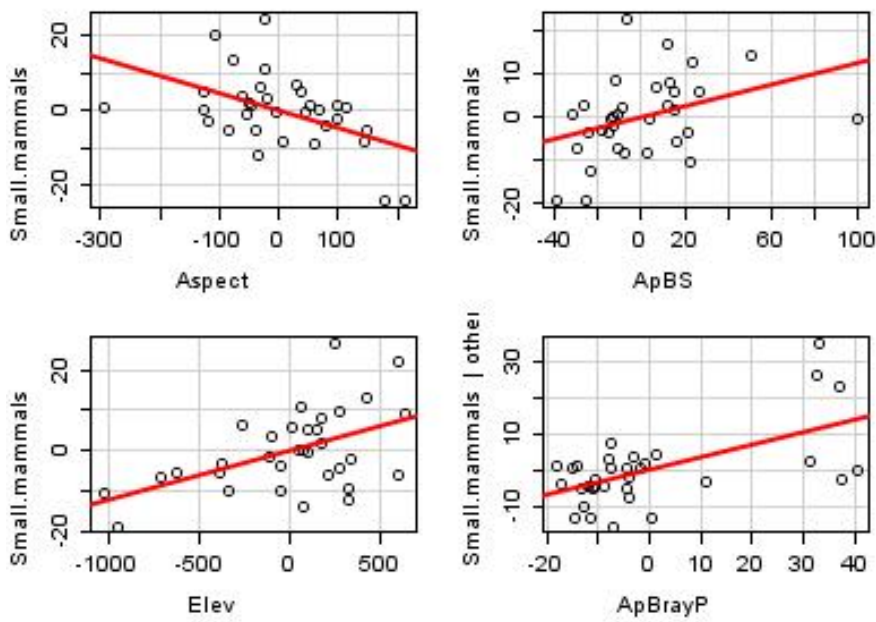

Figure 5: Influence of landform and soil properties on the occurrence of small mammals (Slope aspect $=$ aspect of the surface towards the direction of great gradient $(A p B S=$ topsoils $(0-45 \mathrm{~cm})$ base saturation of soils; ApBrayP = Available Bray phosporus; Elev = Elevation of the area)

Figure 5 presents results which identify elevation as the most influencing landform factor. The number of small mammals increases with increasing elevation

Influence of landforms and associated soil properties on flea abundance

Table 4 presents the influence of landforms and soil properties on fleas' abundance. The results show that hill-shade and exchangeable magnesium negatively influence flea abundance, significantly at $p=0.001$ and $p=0.01$ respectively. Results further show that available soil phosphorus, base saturation and organic carbon positively influence flea abundance, significantly at probability of $p=0.01$ and $p=0.05$, respectively.

Table 4: Landforms and top-soil predictors of fleas' abundance

\begin{tabular}{lllll}
\hline Variables & Coefficient estimate & Std. Error & t value & $\operatorname{Pr}(>|\mathrm{t}|)$ \\
\hline (Intercept) & 20.889 & 12.493 & 1.67 & 0.1075 \\
Elevation $(\mathrm{m})$ & 0.0097 & 0.005 & 1.82 & 0.0821 \\
Hill-shade & -0.3039 & 0.066 & -4.63 & $0.00011 * * *$ \\
Flow direction & 0.0665 & 0.038 & 1.74 & 0.0950 \\
OC (\%) & 2.9399 & 1.409 & 2.09 & $0.0477 *$ \\
Available Bray P & 0.3319 & 0.094 & 3.55 & $0.0016 * *$ \\
Exchangeable Ca & -0.6331 & 0.465 & -1.36 & 0.1856 \\
Exchangeable Mg & -3.6939 & 1.670 & -2.21 & $0.0368 *$ \\
Base saturation & 0.4296 & 0.138 & 3.11 & $0.0048 * *$
\end{tabular}

Significant codes: $0^{1 * * * 1} 0.001^{1 * * 1} 0.01^{\prime * 1} 0.05^{\prime}$. ' $^{\prime} 0.1^{\prime \prime} 1$

(Dispersion parameter for Gaussian family; Null deviance: 5524.2 on 32 degrees of freedom, Residual deviance: 1850.7 on 24 degrees of freedom. AIC: 246.53) 


\section{Discussion}

The observed landforms, geology and faulting in the study area are complex. The landscapes are characterised by steep upwardly convex and upwardly concave surfaces which influence convergence and divergence of water flows, soil water content and soil water retention characteristics. These conditions are reported to influence multiple factors along the land surface including soil formation and the occurrence of small mammals, fleas and human activities (Monjeau et al., 1997; Jake et al., 1997; Randhir, 2007) due to their influence on soil development which in turn influences vegetation establishment. The results of the current study are in line with various hydrological studies which show that slope facets on the landform influence water flows (Lindsay, 2005) and therefore food access and vegetation habitat for small mammals (Monjeau et al., 1997).

Verma et al. (2005) and Jiang et al. (2006) argued that landforms greatly influence variability and distribution of soil macronutrients. Moore et al. (1993) and Gessler et al. (2000) reported that the development of catenary soil properties occurs as response to the way water moves through and over the landscape, governed by surface characteristics (convergence and divergence). Other works indicated that the soil-landscape pattern results from an integration of short and long term pedogeographic processes (Bockheim et al., 2005; Van de Wauw et al., 2008).

The slope aspect which is modulated by slope gradient also influences slope local climate especially solar radiation and exposure to wind (Warren et al., 2013; Goudie, 2013). Slope aspect therefore impacts on vegetation habitat and differential soil development. The slope aspect is among strong predictors of small mammal abundance in the study area. This conforms to report by Urban \& Swihart (2010) that species richness was influenced by slope aspect in Indiana, USA.

The current study explains the influence of landforms on the abundance of small mammals and fleas. The observed results could be attributed to a theory of elevation diversity gradient (McCain, 2005) which takes into account integration of multiple ecological factors including elevation, heterogeneity of landforms, soils, rainfall, temperature, habitat types and resources availability (Rosenzweig, 1992; Rahbek, 1995; Heaney, 2001; Sanchez-Cordero, 2001; Grytnes \& Vetaas, 2002; Ackerly, 2003; Pavoine \& Bonsall, 2010). Results from the current study show unique assemblages of species per landform type, with diversity and evenness increasing with elevation. These results shed light in explaining partly why there is plague where it is and why it is not where it is not in the West Usambara Mountains. For example the Plain part of the landscape was found to harbour small mammals species that have not been reported to host the plague bacterium as compared to those species in the Plateau where the plague disease has been reported frequently (Kilonzo et al., 2005; Davis et al., 2006).

The abundance of small mammals has been influenced by multiple ecological factors operating together. These multiple factors include elevation, slope and soil which explain in an integrated way the presence of small mammal species. According to Rosenzweig (1992), there are many mechanisms that operate together to influence biodiversity changes in communities. The mechanisms act together and in the ecosystem none works in isolation (McCain, 2005). The landforms in the study area have distinctive characteristics in terms of rainfall which is low in the Plain and increases gradually with elevation from 500 to $800 \mathrm{~mm}$ per year in the upper part of Escarpment and Plateau. The soils are mainly Cambisols and Fluvisols in the Plain, Regosols and Leptosols in the Escarpment and more highly developed and weathered very deep, well drained soils (Acrisols, Lixisols, Alisols and Luvisols) in the Plateau. Fluvisols and Gleysols dominate in the valley bottoms and depressions. So, the observed abundance of small mammals and their associated fleas may have possibly been dictated by multiple factors namely landforms, soils, and climate, among others. These also influence the richness, evenness and diversity of species (McCain, 2005), because they impact resource availability including food, water and shelter (Heaney, 2001; Pavoine \& Bonsall, 2010). 
The large number of small mammals and fleas in high elevations of the West Usambara Mountains corresponds with the high plague frequency landscapes. Already previous studies in the area have shown that every plague outbreak was preceded by rodent outbreak (Kamugisha et al., 2007). Similar results have been reported by Neerinckx et al. (2010) and Eisen et al. (2012) in Tanzania and Uganda, respectively.

The influence of landforms and soil properties on small mammals' abundance shows that there was a positive correlation between available phosphorus, base saturation, and the small mammals' abundance. However, there was a negative correlation between small mammals' abundance and slope aspect in the area; and this could be attributed to the influence of slope aspect on climatic factors negatively affecting vegetation habitat, food and water resources which are important for small mammals' habitation (Busch et al., 2000). Results of the current study indicate a strong influence of phosphorus on small mammals probably because of its availability in adequate levels which favours vegetation growth, hence providing cover and habitat to rodents (Mulungu et al., 2008) but also food and herbage (Krebs, 2001).

The influence of landforms and soil properties on flea abundance declines with increased hill-shade, exchangeable calcium and magnesium while their population increases with increasing elevation, available phosphorus and base saturation. Although the abundance of fleas follows a similar trend as that of small mammals, literature shows that flea survival and richness is dependent on local microclimatic factors like soil relative humidity fluctuations and temperature (Krasnov et al., 2001; Enscore et al., 2002; Gage \& Kasey, 2005; Sternest et al., 2006). Temperature has been reported to influence flea egg laying, egg survival and flea reproduction and development (Eisen et al., 2012). Soil attributes are important because they influence moisture retention and humidity in burrows (Biggins, 2012). This could explain why there were few fleas in the drier Plain and more in the moist Plateau. Also, other studies have reported that the vectors encountered in a given area are related to specific locations and host species (Kennedy \& Bush, 1994; Caro et al., 1997; Krasnov et al., 2005), and this account for the observed correlation between fleas' richness and trapped small mammals.

It is concluded that landforms and soils have a strong influence on the richness and evenness of small mammals and their flea abundance. Elevation and slope aspect are strong landform predictors, whereas available phosphorus and base saturation are strong soil predictors for richness and evenness of both small mammal and flea abundance. Abundance of fleas was mainly influenced by hill-shade and available phosphorus, organic carbon and exchangeable magnesium. Our insight into the dynamics of small mammals and fleas in relation to soils and landforms in the plague focus of the West Usambara Mountains has contributed to the debated 'plague-host-vector' relationships. This understanding may possibly facilitate better ways of managing plague host outbreaks. It was observed that most rodents which are implicated for being plague hosts were found in the upper parts of the escarpment and their habitats were identified. It is recommended to step up surveillance of rodent population in those habitats so as to check and control plague in the nearby communities.

\section{Acknowledgements}

This work was supported by the SUA-VLIR Own Initiative Project through a project with Acronym LEPUS, financed by VLIR, Belgium. The authors are grateful to many people in Lushoto District who facilitated this work in different ways: Lushoto District Executive Director, District Agricultural and Livestock Development Officer, Sebastian Kolowa Memorial University, Tanzania, Lushoto District Subject Matter Specialists-Land Use and Health, village leaders, and farmers. 


\section{References}

Ackerly, D.D. (2003) Community assembly, niche conservatism, and adaptive evolution in changing environments. International Journal of Plant Sciences 164, 165-184.

Anisimov, A.P. (2002) Factors of Yersinia pestis providing circulation and persistence of plague pathogen in ecosystems of natural foci. Molekuliarnaia Genetika, Mikrobiologiia Virusologiia 4, 3-11.

Ayyadurai, S., Houhamdi, L., Lepidi, H., Nappez, C., Raoult, D. \& Drancourt, M. (2008) Long-term persistence of virulent Yersinia pestis in soil. Microbiology 154, 2865-2871.

Biggins, D. (2012) Effects of soil and colony age on flea densities. [http://www.fort.usgs.gov/Research/research_tasks.asp?TaskID=2380]. Accessed on 24.09.2013.

Bockheim, J.G., Gennadiyev, A.N., Hammer, R.D. \& Tandarich, J.P. (2005) Historical development of key concepts in pedology. Geoderma 124, 23-36.

Brabers, L. (2012) Land Characteristics, Soil Properties and Microclimate Associated with Rodent Burrows in a Selected Plague Focus, Lushoto District, Tanzania. MSc Dissertation, Katholieke Universiteit Leuven, Belgium, 85pp.

Breneva, N.V., Maramovich, A.S. \& Klimov, V.T. (2006) The population variability of Yersinia pestis in soil samples from the natural focus of plague. Zhurnal Mikrobiologii Epidemiologii Immunobiologii March/April: 7-11.

Caro, A., Combes, C. \& Euzet, L. (1997) What makes a fish a suitable host for Monogenea in the Mediterranean. Journal of Helminthology 71, 203-210.

Davis, S., Makundi, R.H., Machang'u R.S. \& Leirs, H. (2006) Demographic and spatio-temporal variation in human plague at a persistent focus in Tanzania. Acta Tropica 100, 133-141.

Deb, D.L. \& Sakal, R. (2002) Micronutrients. In: Indian Society of Soil Science. Indian Research Institute, New Delhi. pp. 391-403.

Drancourt, M., Houhamdi, L. \& Raoult, D. (2006) Yersinia pestis as a telluric, human ectoparasiteborne organism. Lancet Infectious Diseases 6, 234-241.

Eisen, R.J., Borchert, J.N., Mpanga, J.T., Atiku, L.A., MacMillan, K., Boegler, K.A., Montenieri, J.A., Monaghan, A. \& Gage, K.L. (2012) Flea diversity as an element for persistence of plague bacteria in an East African Plague Focus. PLoS One 7(4), 1-8.

Eisen, R.J., Petersen, J.M., Higgins, C.L., Wong, D., Levy, C.E., Mead, P.S., Schriefer, M.E., Griffith, K.S., Gage, K.L. \& Beard, C.B. (2008) Persistence of Yersinia pestis in soil under natural conditions. Emerging Infectious Diseases 14, 941-943.

Enscore, R.E., Biggerstaff, B.J., Brown, T.L., Fulgham, R.F. \& Reynolds, P.J. (2002) Modelling relationships between climate and the frequency of human plague cases in the southwestern United States, 1960-1997. American Journal of Tropical Medicine and Hygiene $66,186-196$.

Fellows, I. (2012) Deducer: An R Graphical User Interface for Everyone. [http://www.Deducer.org/manual.html]. Accessed on 20.10.2012.

Gage, K.L., Burkot, T.R., Eisen, R.J. \& Hayes, E.B. (2008) Review climate and vector-borne diseases. American Journal of Preventive Medicine 35, 436-350.

Gage, K.L. \& Kasey, M.Y. (2005) Natural history of plague: perspective from more than a century of research. Annual Reviews of Entomology 50, 505-528.

Gessler, P. E., Chadwick, O. A., Chamran, F., Althouse, L. \& Holmes, K. (2000) Modeling soillandscape using terrain attributes. American Society of Agronomy 64(6), $2046-2056$.

Goudie, A. (2013) Encyclopedia of Geomorphology 437 pp.

Grytnes, J.A. \& Vetaas, O.R. (2002) Species richness and altitude: a comparison between null models and interpolated plant species richness along the Himalayan altitudinal gradient, Nepal. American Naturalist 159, 294-304. 
Heaney, L.R. (2001) Small mammal diversity along elevational gradients in the Philippines: an assessment of patterns and hypotheses. Global Ecology and Biogeography 10, 15-39.

Jake, F. W., Steve, A. \& Rod, K. H. (1997) Small-mammal regulation of vegetation structure in a temperate savanna. Ecology 78, 751-763.

Jiang, Y., Hao, W., Zhang, Y. G. \& Liang, W.J. (2006) Changes in soil nutrients with profile depth in aquic brown soil under different land uses. Journal of Soil and Water Conservation 20, 9396.

Kamugisha, M.L., Gesase, S., Minja, D., Mgema, S., Mlwilo, T.D., Mayala, B.K., Msingwa, S., Massaga, J.J. \& Lemnge, M.M. (2007) Pattern and spatial distribution of plague in Lushoto, North-Eastern Tanzania. Tanzania Health Research Bulletin 9, 12-17.

Kennedy, C.R. \& Bush, A.O. (1994) The relationship between pattern and scale in parasite communities: a stranger in a strange land. Parasitology 109, 187-196.

Kilonzo, B. S. \& Msangi, A. S. (1991) Plague. In: Health and diseases in Tanzania (Ed: G.M. Mwaluko) Harper Collins, London. pp. $98-116$.

Kilonzo, B., Mhina, J., Sabuni, C. \& Mgode, G. (2005) The role of rodents and small carnivores in plague endemicity in Tanzania. Belgian Journal of Zoology 135, 119-125.

Kingdon, J. (1974) East African mammals: An atlas of evolution in Africa. Academic Press, London 2, 343-704.

Kingdon, J. (1997) The Kingdom Field Guide to African Mammals. Harcout Brace and Company, New York, 364pp.

Krasnov, B.R., Stanko, M., Miklisova, D. \& Morand, S. (2005) Distribution of fleas (Siphonaptera) among small mammals: mean abundance predicts prevalence via simple epidemiological model. International Journal of Parasitology 35, 1097-1101.

Krasnov, B.R., Khokhlova, I.S., Fielden, L.J. \& Burdelova, N.V. (2001) Effect of air temperature and humidity on the survival of pre-imaginal stages of two flea species (Siphonaptera: Publicidae). Journal of Medical Entomology 38, 629-637.

Krebs, C.J. (2001) Ecology the Experimental Analysis of Distribution and Abundance. Addison Wesley Longman Inc., New York. 695pp.

Laudisoit, A., Leirs, H., Makundi, R.H., Van Dongen, S., Davis, S., Neerinckx, S., Deckers, J. \& Libois, R. (2007) Plague and the human flea, Tanzania. Emerging Infectious Diseases 13, 687-693.

Lindsay, J.B. (2005) The terrain analysis system: A tool for hydro-geomorphic applications. Hydrological Processes 19, $1123-1130$.

MacMillan, K., Enscore, R.E., Ogen-Odoi, A., Borchert, J.N., Babi, N., Amatre, G., Atiku, L.A., Mead, P.S., Gage, K.L. \& Eisen, R.J. (2011) Landscape and residential variables associated with plague-endemic villages in the West Nile Region of Uganda. American Journal of Tropical Medicine and Hygiene 84, 435-442.

McCain, M.C. (2005) Elevational gradients in diversity of small mammals. Ecology 86, 366-672.

Monjeau, J.A., Sikes, R.S., Birney, E.C., Guthmann, N. \& Phillips, C.J. (1997) Small mammal community composition within the major landscape divisions of Patagonia, Southern Argentina. Mastozoología Neotropical 4, $113-127$.

Meade, M.S. \& Earickson, R.J. (2000) Medical Geography. The Guilford Press, New York. 428pp.

Moore, I.D., Gessler, P.E., Nielsen, G.A. \& Peterson, G.A. (1993) Prediction using terrain analysis. American Society of Agronomy 57, 443-452.

Moberg, J.P. (2000) Soil Analysis Manual. KVL, Copenhagen, Denmark. 133pp.

Mulungu, L.S., Makundi, H.R., Massawe, A.P., Machangu, R.S. \& Nsajigwa, E.M. (2008) Diversity and distribution of rodent and shrew species associated with variations in altitude on Mount Kilimanjaro, Tanzania. Mammalia 72, 178-185.

Neerinckx, S., Peterson, A.T., Gulinck, H., Deckers, J., Kimaro, D., \& Leirs, H. (2010) Predicting potential risk areas of human plague for the Western Usambara Mountains, Lushoto District, Tanzania. American Journal of Tropical Medicine and Hygiene 82, 492-500. 
Neerinckx, S. (2010) Insights in the Ecology of Plague Using Spatial and Ecological Models at Distinct Scales and Resolutions. PhD Thesis, Katholieke Universitiet Leuven and Universiteit, Antwerpen, Belgium, 196pp.

Pavoine, S. \& Bonsall, M.B. (2010) Measuring biodiversity to explain community assembly: A unified approach. Biological Reviews 2, $1-21$.

Pavlovsky, E.N. (1966) Natural Nidality of Transmissible Diseases. University of Illinois Press, Urbana. 261pp.

Rahbek, C. (1995) The elevational gradient of species richness - a uniform pattern. Ecography 18, 200-205.

Randhir, T.O. (2007) Watershed Management: Issues and Approaches. IWA Publishing, 56pp.

Rotshild, E.V. (1978) Spatial Structure of a Natural Center of Plague and Methods of Studying it. Izdatelstvo MGU, Moscow. 192pp.

Rosenzweig, M.L. (1992) Species diversity gradients: we know more and less than we thought. Journal of Mammalogy 73, 715-730.

Sanchez-Cordero, V. (2001) Elevation gradients of diversity for rodents and bats in Oaxaca, Mexico. Global Ecology and Biogeography 10, 63-76.

Shannon, C.E. (1948) A mathematical theory of communication. The Bell System Technical Journal $27,379-423$.

Sternest, N.C., Atshabar, B.B., Begon, M., Belmain, S.R., Bertherat, E., Carniel, E., Gage, K.L., Leirs, H. \& Rahalison, L. (2008) Plague: Past, Present, and Future. PLoS Medicine 5:1.

Sternest, N.C., Damia, N.I., Viljugrein, H., Kausrud, K.L., Begon, M., Davis, S., Leirs, H., Dubyanskiy, V.M., Esper, J., Ageyev, V., Klassovskiy, N.L., Pole, S.B. \& Chan, K.S. (2006) Plague dynamics are driven by climate variation. National Academy of Sciences 103, 1311-1315.

Urban, N.A. \& Swihart, R.K. (2010) Small mammals' response to forest management for oak regeneration in Southern Indiana. Forest Ecology and Management 261, 353-361.

URT, (2013) 2012 Population and Housing Census. Population Distribution by Administrative Areas. National Bureau of Statistics, Ministry of Finance, Dar es Salaam, and Office of Chief Government Statistician, President's Office, Finance, Economy and Development Planning, Zanzibar (244pp).

Van de Wauw, J., Baert, G., Moeyersons, J., Nyssen, J., De Geyndt, K., Taha, N., Zenebe, A., Poesen, J. \& Deckers J. (2008) Soil-landscape relationships in the basalt-dominated highlands of Tigray, Ethiopia. Catena 75, $117-127$.

Verma, V.K., Setia, R.K., Sharma, P.K., Singh, C. \& Kumar, A. (2005) Pedospheric variations in distribution of DTPA- extractable micronutrients in soils developed on different physiographic units in Central Parts of Punjab, India. International Journal of Agriculture and Biology 7, 243-246.

Warren, K., Eppes, M.C., Swami, S., Garbini, J. \& Putkonen, J. (2013) Automated field detection of rock fracturing, microclimate, and diurnal rock temperature and strain fields. Geoscientific Instrumentation Methods and Data Systems 2, 275-288.

Witmer, G.W. (2004) Rodent Ecology and Plague in North America. USDA National Wildlife Research Center 4101 LaPorte, venue Fort Collins, Com., USA. 4pp. 